\section{POTENSI ENERGIK AKHLAK}

\section{Asmal May}

Fakultas Tabiyah dan Keguruan UIN Suska Riau, Pekanbaru

\section{Abstract}

The Energical Potent of Akhlak: Human behavior, either good or bad, is designed by some factors that influenced it. Those factors are understood as the basic potentiality that strongly influence toward akhlak in manner to be both constructive and destructive. Those factors come from inside and outside of human being themselves.

Keywords: Akhlak, Ratio, Human Deed, Action.

\section{Pendahuluan}

Kehidupan muslim yang baik dapat menyempurnakan akhlaknya sesuai dengan yang telah dicontohkan oleh Nabi Muhammad saw. Akhlak yang baik dilandasi oleh ilmu, iman, amal dan takwa. Ia merupakan kunci bagi seseorang untuk melahirkan perbuatan dalam kehidupan yang diatur oleh agama. Melalui ilmu, iman, amal dan takwa seseorang dapat berbuat kebajikan, seperti shalat, puasa, berbuat baik sesama manusia dan kegiatan-kegiatan lain yang merupakan interaksi sosial. Sebaliknya tanpa ilmu, iman, amal dan takwa, seseorang dapat berperilaku yang tidak sesuai dengan akhlak al-karimah, sebab ia lupa pada Allah yang telah menciptakannya.

Secara sederhana akhlak dapat diartikan sebagai tingkah laku manusia yaitu sikap seseorang yang dimanifestasikan dalam perbuatan. Sikap seseorang boleh jadi tidak digambarkan dalam perbuatan atau tidak tercermin dalam perilaku sehari-hari tetapi adanya kontradiksi antara sikap dan tingkah laku. Kecenderungan fitrah manusia selalu untuk berbuat baik (haniif). Seseorang itu dinilai berdosa karena pelanggaran-pelanggaran yang dilakukannya, yaitu pelanggaran terhadap norma-norma, seperti melanggar fitrah manusia, melanggar aturan agama dan adat-istiadat. Secara fitrah, seorang muslim dilahirkan dalam keadaan suci. Manusia tidak diwarisi dosa dari orang
Asmal May, Potensi Energik. Akblak

tuanya, karena itu bertentangan dengan hukum keadilan Tuhan. Sebaliknya Allah membekali manusia di bumi dengan akal, fikiran dan iman kepadaNya. Keimanan itu dalam perjalanan hidup manusia dapat bertambah atau berkurang disebabkan oleh berbagai pengaruh dalam hidup yang dialaminya. ${ }^{1}$ Sedikit saja tergelincir, jatuhlah manusia ke lembah kehinaan, hilanglah marwah kemanusiaannya. Oleh karena itu, muncul berbagai persoalan untuk membina dan mempertahankan akhlakul karimah.

\section{Faktor-faktor yang Mempengaruhi Akhlak}

Baik dan buruknya tingkah laku manusia pada hakekatnya sangat ditentukan oleh faktor-faktor yang mempengaruhinya. Faktor-faktor tersebut merupakan potensi dasar yang sangat kuat pengaruhnya terhadap akhlak baik untuk membangun ataupun untuk merusak. Faktor-faktor itu ada yang berasal dalam diri manusia dan ada dari luar diri manusia. Setiap manusia sepanjang hayatnya, baik melakukan perbuatan baik atau buruk tidak terlepas dari beberapa aspek yang mempengaruhinya. Seluruh aspek tersebut berperan penting dalam pertumbuhan dan perkembangan manusia sepanjang hayatnya. Pengaruh itu bersifat ganda, bisa membawa kepada perbuatan yang positif, bisa pula kepada yang negatif, dan seluruh aspek yang berperan itulah yang akan dibahas dalam kajian makalah ini yaitu :

\section{Insting dan Naluri}

Menurut bahasa (etimologi) insting berarti kemampuan berbuat pada suatu tujuan yang dibawa sejak lahir, merupakan pemuasan nafsu, dorongan-dorongan nafsu dan dorongan psikologis. Insting juga merupakan kesanggupan melakukan hal yang kompleks tanpa dilihat sebelumnya, terarah kapada suatu tujuan yang berarti bagi subjek tidak disadari langsung secara mekanis.

Menurut James insting ialah suatu sifat yang menyampaikan pada tujuan dan cara berfikir. ${ }^{2}$ Insting merupakan kemampuan yang

1 Zakiah Daradjat, Dasar-Dasar Agama Islam, (Jakarta: Universitas Terbuka, 2002), Cet. ke 2, hlm. 273.

2 Ahmad Amin, Etika Ilmu Akblak. (Jakarta: Bulan Bintang, 1996), hlm.13. 
Al-Fikra: Jurnal Ilmiah Keislaman, Vol. 8, No. 1, Januari-Juni 2009

melekat sejak lahir dan dibimbing oleh naluriahnya. Insting pada binatang untuk pemenuhan kebutuhan, umumnya seperti mencari makanan, mengenali musuh dan mengenali lawan jenis untuk kawin Dorongan insting pada manusia, menjadi faktor tingkah laku dan aktivitas dalam mengenali sesama manusia. Masing-masing makluk hidup dapat mempertahankan dirinya melalui insting agar tetap hidup dan tidak mati.

Insting pada intinya ialah suatu kesanggupan untuk melakukan perbuatan yang tertuju kepada sesuatu pemuasan dorongan nafsu atau dorongan batin yang telah dimiliki manusia maupun hewan sejak lahir. Insting pada hewan bersifat tetap, tidak berubah dari waktu ke waktu, sejak lahir sampai mati. Insting pada manusia dapat berubah dan dapat dibentuk secara instensif.

Dalam insting terdapat tiga unsur kekuatan yang bersifat psikis yaitu mengenal (kognis), kehendak (konasi) dan perasaan (emosi). Unsurunsur ini juga terdapat pada binatang. Insting yang juga disebut naluri, merupakan dorongan nafsu yang timbul dalam batin untuk melakukan suatu kecenderungan khusus dari jiwa yang dibawa sejak ia dilahirkan. Insting merupakan sejumlah gerak energi dari semua jenis insting, yakni merupakan keseluruhan energi psikis yang dipergunakan oleh kepribadian. Insting terdiri dari empat pola khusus, yaitu:

1. Sumber insting, berasal dari kondisi jasmaniah untuk melakukan kecenderungan, lama-lama menjadi kebutuhan.

2. Tujuan insting, yaitu menghilangkan rangsangan jasmaniah, untuk menghilangkan perasaan tidak enak yang timbul karena adanya tekanan batin yang disebabkan oleh meningkatnya energi pada tubuh.

3. Objek insting, merupakan segala aktivitas yang mengantar keinginan dan memilah-milah agar keinginannya dapat terpenuhi.

4. Gerak insting, tergantung kepada intensitas (besar-kecilnya) kebutuhan.

Insting pada tingkat tertentu selalu berubah, boleh jadi ia hidup dan boleh jadi mati. Perobahan tersebut adalah sebagai berikut:
Asmal May, Potensi Energik. Akblak

a. Insting hidup, berfungsi melayani individu untuk tetap hidup dan memperpanjang ras. Bentuk utama insting ini adalah insting makan-minum dan seksual. Islam mengajarkan agar manusia makan makanan yang halal lagi baik.

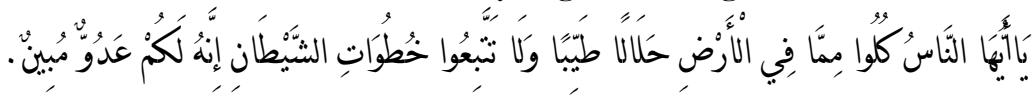

Hai sekalian manusia, makanlah dari apa saja yang terdapat di bumi yang halal lagi baik, dan janganlah kamu mengikuti langkah-langkah syaitan; karena sesunggubnya syaitan itu adalah musub yang nyata bagimu. (Q.S. Al-Baqarah: 168)

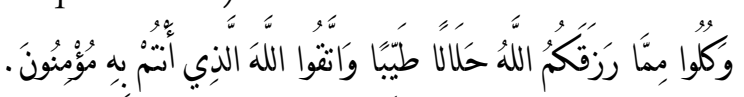

Dan makanlah makanan yang halal lagi baik dari apa yang Allah telah reqkikan kepadamu, dan bertakwalah kepada Allah, hanya kepada Allablah kamu beriman. (Q.S. Al-Maidah: 88)

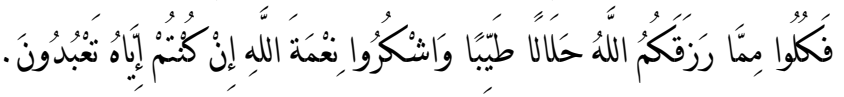

Maka makanlah (makanan) yang halal lagi baik dari rezki yang telah diberikan Allah kepadamu; dan bersyukurilah atas ni mat Allah, jika kamu benar-benar hanya menyembah kepada-Nya.(Q.S. An-Nahl: 144).

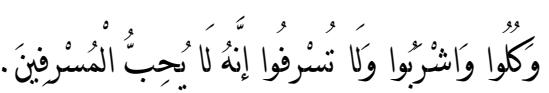

...makan dan minumlah (kamu), dan janganlah berlebib-lebihan. Sesunggubnya Allah tidak menyukai orang-orang yang berlebiblebihan.(Q.S. al-A'raf: 31).

Insting seksual yang terdapat pada manusia, Allah memberi kesempatan untuk melakukan hubungan sek, namun harus melalui nikah. Allah ciptakan istri-istri untuk cenderung padanya dan saling mencintainya. Allah berfirman:

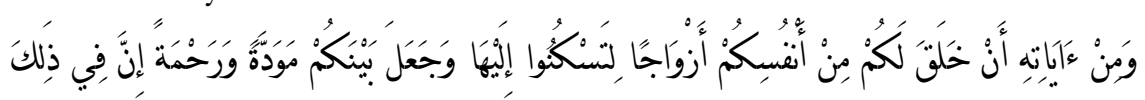

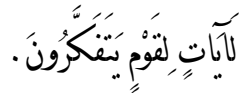


Al-Fikra: Jurnal Ilmiah Keislaman, Vol. 8, No. 1, Januari-Juni 2009

Dan di antara tanda-tanda Kekuasaan-Nya ialah Dia menciptakan untukmu isteri-isteri dari jenismu sendiri, supaya kamu cenderung dan merasa tenteram kepadanya, dan dijadikan-Nya di antaramu rasa kasih dan sayang. Sesunggubnya pada yang demikian itu benar-benar terdapat tanda-tanda bagi kaum yang berfikir. (Q.S. Ar-Rum: 21).

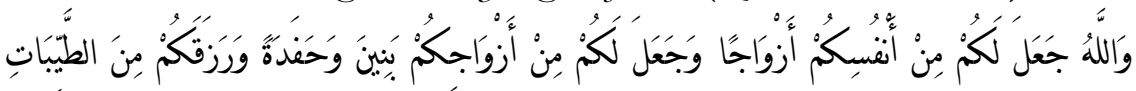

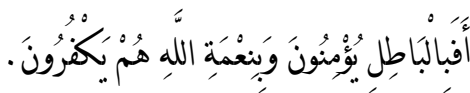

Allah menjadikan bagi kamu isteri-isteri dari jenis kamu sendiri dan menjadikan bagimu dari isteri-isteri kamu itu, anak-anak dan cucu-cucu, dan memberimu rezki dari yang baik-baik. Maka mengapakah mereka beriman kepada yang bathil dan mengingkari ni mat Allab? (Q.S. AnNahl: 72).

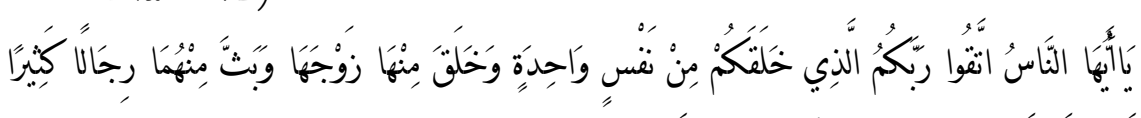

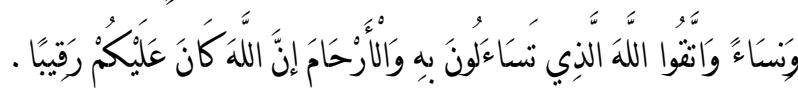

Hai sekalian manusia, bertakwalah kepada Tuhan-mu yang telah menciptakan kamu dari diri yang satu, dan dari padanya Allab menciptakan isterinya; dan dari keduanya Allab memperkembang biakkan laki-laki dan perempuan yang banyak. Dan bertakwalah kepada Allah yang dengan (mempergunakan) nama-Nya kamu saling meminta satu sama lain dan (peliharalah) bubungan silaturrabim. Sesunggubnya Allah selalu menjaga dan mengawasi kamu. (Q.S. AnNisa': 1).

Dalil-dalil ini menunjukkan bahwa seksual adalah fitrah manusia yang harus disalurkan melalui nikah. Untuk menciptakan keluarga sakinah, mawaddah, warahmah, Allah memberikan kebebasan seksual sebebas-bebasnya sesuai dengan berfirmanNya.

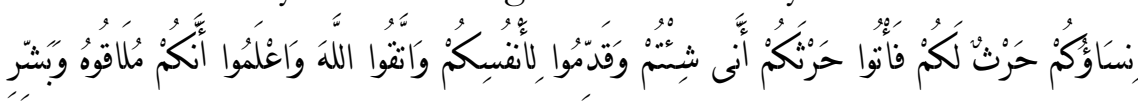

Asmal May, Potensi Energik Akblak

Isteri-isterimu adalah (seperti) tanah tempat kamu bercocok-tanam, maka datangilah tanah tempat bercocok-tanammu itu bagaimana saja kamu kehendaki. Dan kerjakanlah (amal yang baik) untuk dirimu, dan bertakwalah kepada Allah dan ketahuilah bahwa kamu kelak akan menemui-Nya. Dan berilah kabar gembira orang-orang yang beriman. (Q.S. Al-Baqarah: 223).

Untuk menjaga sopan-santun terhadap istri dan tatakrama dalam hubungan seksual Nabi mengingatkan:

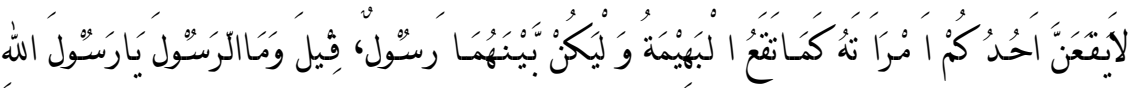

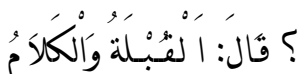

Jangan sekali-kali seseorang mencampuri istrinya sebagaimana yang terjadi pada binatang. Hendaklah ada diantara keduanya perantara. Kemudian Rasul ditanya (sahabat): Apakah perantara itu ya Rosulullab? Jawabnya, mencium dan bercumbu mesra. (HR. Darulqutni).

Dari dalil-dalil tersebut jelaslah bahwa hubungan seksual benarbenar mendapat perhatian khusus dalam Islam. Khusus di bulan Romadhon Allah perintahkan menahan diri untuk puasa pada siang hari, namun masih diberi kesempatan untuk melakukan hubungan seksual sebebas-bebasnya pada malam hari. Allah berfirman:

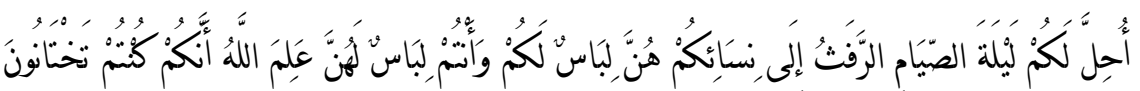

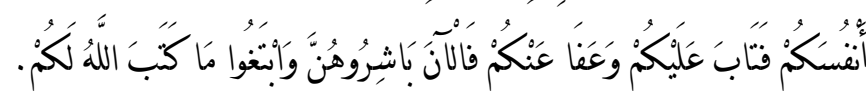

Dibalalkan bagi kamu pada malam hari bulan Puasa bercampur dengan isteri-isteri kamu; mereka itu adalah pakaian bagimu dan kamu pun adalah pakaian bagi mereka. Allah mengetahui bahwasanya kamu tidak dapat menahan nafsumu, karena itu Allah mengampuni kamu dan memberi ma af kepadamu. Maka sekarang campurilah mereka dan carilah apa yang telah ditetapkan Allah untukmu. (Q.S. Al-Baqarah: 186).

b. Insting mati disebut juga insting merusak. Fungsi insting ini kurang jelas jika dibandingkan dengan insting-insting hidup, 
Al-Fikra: Jurnal Ilmiah Keislaman, Vol. 8, No. 1, Januari-Juni 2009

karena insting ini tidak begitu dikenal. Suatu derivatif instinginsting mati yang terpenting adalah dorongan agresif. Sifat agresif adalah pengurusan diri yang diubah dengan objek substitusi. Insting hidup dan insting mati, keduanya dapat saling bercampur. ${ }^{3}$

Ada beberapa ciri-ciri gerak insting yang dapat diamati. Ciri-ciri tersebut adalah sebagai berikut:

1. Insting lebih mejemuk dari refleks. Gerak-gerak insting lebih kompleks dari pada gerak-gerak refleks yang serba terikat dengan jenis perangsang.

2. Insting merupakan kemampuan untuk bergerak kepada suatu tujuan dengan tidak memerlukan latihan lebih dahulu.

3. Insting merupakan pembawaan, kemampuan alami yang dibawa sejak lahir.

4. Insting berjalan secara mekanis, tanpa menggunakan kesadaran dan pertimbangan.

5. Insting dapat dilatih dan diubah, disesuaikan dengan keadaankeadaan baru.

6. Insting berakar pada dorongan nafsu dan dorongan lain untuk mendapatkan kepuasan.

7. Insting pada hewan sejak lahir tetap tidak berubah, gerak insting pada manusia berubah-ubah.

Perbedaan insting pada hewan dan insting pada manusia adalah sebagai berikut:

1. Insting pada hewan dapat bergerak di mana perlu dan di mana ada kesempatan. Insting pada hewan dapat memenuhi kebutuhan hidupnya dengan cara yang tetap, tidak berubahubah. Insting pada hewan hanya hidup dan bergerak dalam keadaan yang serba berubah, namun insting hewan tetap tidak berubah sampai mati.

2. Insting pada manusia tidak sama dengan hewan. Manusia mempunyai dorongan insting yang mirip hewan, tetapi

3 Sumadi Suryabrata, Psikologi Kepribadian (Jakarta: Raja Grafindo Persada, 1995), hlm. 129-133.
Asmal May, Potensi Energik. Akblak

perbuatan dan hidup manusia tidak dikuasai oleh dorongan insting, melainkan menggunakan akal fikiran.

3. Pada suatu kesempatan insting hewan tetap berfungsi, insting pada manusia sudah dalam bentuk perbuatan yang dipengaruhi oleh akal dan fikiran.

Dalam ilmu akhlak insting berarti akal-fikiran. Akal dapat memperkuat akidah, namun harus ditopengi ilmu, amal dan takwal pada Allah. Allah memuliakan akal dengan dijadikannya sebagai sarana tepat tanggung jawab. Diantara mereka ada yang menerimanya dengan cara melalui hafalan dan dipercayai sebagai adat kebiasaan (kepercayaan tradisional). Kepercayaan ini tidak luput dari timbulnya kebimbangan dan keraguan. Ada yang memperolehnya dengan jalan memperhatikan dan berfikir sehingga kepercayaannya semakin mendalam dan keyakinannya semakin kuat. ${ }^{4}$

Perbedaan utama antara insting manusia dengan insting bianatang terletak pada kemapuan manusia mengambil jalan melingkar dalam mencapai tujuannya. Seluruh insting binatang dipenuhi oleh kebutuhan yang menyebabkan mereka secara langsung mencari objek yang diinginkannya atau membuang benda yang dihalanginya. Sebaliknya manusia dilengkapi dengan akal fikiran, dalam melakukan kegiatan ia menggunakan akal fikir dengan sempurna dan sarana penunjang berupa bahasa, logika, matematika dan statistika. Berdasarkan pemikiran ini, dapatlah diketahui bahwa tidak sukar untuk membedakan antara insting dan naluri.

Akal adalah jalinan fikir dan rasa yang menjadikan manusia, berlaku, berbuat, membentuk masyarakat dan membina kebudayaan. Akal menjadikan manusia itu mu'min, muslim, muttaqin, shalihin. Agama itu akal, maka hanya dengan akallah dapat memahami Allah, akal merupakan kunci untuk memahami Islam. ${ }^{5}$

${ }^{4}$ Syekh Hasan al-Banna, Aqidah Islam, Cet. ke 2 (Bandung: PT.Al-Maa'rif, 1983), hlm. 9

5 Jujun.S.Surya Sumantri, Filsafat, Cet. ke 16 (Jakarta: Total Grafika Indonesia, 2003), hlm. 167. 
Al-Fikra: Jurnal Ilmiah Keislaman, Vol. 8, No. 1, Januari-Juni 2009

Naluri merupakan asas tingkahlaku perbuatan manusia. Manusia dilahirkan dengan membawa naluri yang berbentuk proses pewarisan urutan nenek moyang. Naluri dapat diartikan sebagai kemauan taksadar yang dapat melahirkan perbuatan mencapai tujuan tanpa berfikir kearah tujuan dan tanpa dipengaruhi oleh latihan berbuat. Tingkah laku perbuatan manusia sehari-hari dapat ditunjukan oleh naluri sebagi pendorong. Contoh; tindakan makan ialah naluri lapar dan berpakaian naluri malu, demikianlah tiap tindakan dapat ditemukan dalam naluri sebagai pendorong.

Ahmad Amin menganggap naluri manusia sangat penting untuk:

- Menjaga diri pribadi semenjak lahirnya, manusia berusaha untuk mempertahankan hidup berkembang dan melanjutjkan hidup;

- Menjaga jenis kelamin dalam hubungan cinta antara laki-laki dan perempuan, kasih sayang antara orang tua dan anak;

- Takut berakar dalam diri, manusia mengikutnya mulai masa kanak-kanak sampai dewasa dan masuk kubur.

Disamping itu banyak insting yang mendorong perilaku perbuatan yang menjurus kepada akhlak al-karimah maupun akhlak almazmumah, tegantung orang yang mengendalikannya. Apabila dikaji secara menyeluruh, ada bermacam-macam naluri yang bersemayam dalam batin manusia. Naluri-naluri itu berakar pada hati sanubari manusia pada dua asas pokok yaitu; [1] Naluri asas keselamatan dan [2] Naluri asas kesenangan.

Perbedaan yang sangat nyata antara analuri manusia, hewan dan tumbuhan ialah bahwa naluri manusia dapat didik, naluri hewan tetap tidak berubah dari waktu kewaktu, begitu juga naluri pada tumbuhtumbuhan. Menurut teori evolusi, naluri hewan dan tumbuhan dapat timbul, maju dan mundur sebagai jawaban terhadap linghkungannya. Naluri pada manusia merupakan sifat pertama yang membentuk akhlak. Tetapi sifat itu masih bersahaja, ia tidak diabaikan atau dibiarkan saja melainkan wajib dididik dan dilatih.

Keadaan pribadi manusia bergantung pada jawaban asalnya terhdap naluri. Akal dapat menerima naluri tertentu, sehingga
Asmal May, Potensi Energik. Akblak.

terbentuk kemauan yang melahirkan tindakan. Akal dapat mendesak naluri, sehingga keinginan hanya merupakan riak saja. Akal dapat mengendalikan naluri sehingga terwujud perbuatan yang diputuskan oleh akal. Hubungan naluri dan akal membentuk kemauan. Kemauan melahirkan tingkah laku perbuatan. Nilai tingkah laku perbuatan menentukan nasib seseorang. Naluri yang ada diri seseorng adalah takdir Tuhan. ${ }^{4}$

\section{Pola Dasar Bawaan}

Manusia memiliki sifat ingin tahu, karena dia datang ke dunia ini dengan serba tak tahu (La ta'lamuna syai-an). Apabila seorang mengetahui suatu hal dan ingin mengetahui sesuatu yang belum diketahui, bila diajarkan padanya maka ia merasa sangat senang hatinya. Tingkat kesenangan itu dapat dibagi dua yaitu; [1] Lazaat yaitu kepuasan dan [2] Sa'adah yaitu kebahagiaan.

Bertambah banyak yang diketahui, bertambah naiklah tingkat kepuasan dan bertambah rasa kebahagiaan. Ini hanya dapat dirasakan secara utuh dan sempurna bagi orang yang lebih luas ilmu pengetahuan dan keimanannya. Puncak tertinggi dari kepuasan dan kebahagiaan ini ialah ma'rifatullah.

Manusia mempunyai penyempurnaan pribadi untuk mewujudkan nafsu mutmainnah. Nafsu mutmauinnah artinya jiwa tenang yang merupakan pencerminan dari sikap pribadi seseorang yang diwiujudkan dalam tingkah laku dan perbuatannya sehari-hari Sikap jiwa yang tenang dalam menghadapi segala permsalahan hidup yang dihadapi oleh manusia, menunjukan tingkat kematangan jiwa dan kemantapan diri. Sebagai orang muslim yang menyesuikan kehidupannya dengan jalan kehidupan yang telah ditunjukan oleh Allah. Dalam kaitan antara hak dan kewajiban, ia tidak merasa mendahulukan hak dari kewajiban tetapi ia mendahulukan kewajibannya terhadap agama Islam seperti mempelajari, mengamalkan dan meyebarkan agama Islam.

4 Sidi Gazalba, Asas Kebudayaan Islam, Cet. ke 1 Jakarta: Bulan Bintang, 1978), hlm. 111. 
A1-Fikra: Jurnal Ilmiah Keislaman, Vol. 8, No. 1, Januari-Juni 2009

Dalam hubungan bermasyarakat ia tidak mendahulukan kepentingan individualnya dari kepentingan masyarakat, tap mendahulukan kepentingan masyarakat dari kepentingan dirinya. Ia menyadari apa yang menjadi tugas dan tanggung jawabnya sebagai manusia dan sebagi anggota masyarakat. Ia selalu berusaha mewujudkannya dalam kehidupan sehari-hari. Dalam suaka maupun duka, sempit maupun lapang ia selalu mewujudkan sikap yang tenang. Tidak ada keraguan, tidak ada kekhawatiran, tidak ada kecemasan, tapi ia mempunyai sikap jiwa yang tenang dan optimis, percaya kepada dirinya kepada kemaha kuasaan Tuhan yang menciptakan alam semesta ini karena ia telah memasukkan seluruh jiwa, seluruh hidup dan kehidupannya kedalam Islam.

Seorang muslim dapat mencapai tingkat nafsu mutmainah, apabila ia dapat mencapai tingakt keimanan yang sempurna kepada Allah dalam arti keimanan yang disertai tingkat pemahaman, pengetahuan dan penghayatan yang tinggi terhadap agama Islam sehari-hari. Ia mempunyai pandangan yang optimis dalam hidupnya tidak gelisah tidak kecil hati dan tidak takabur dalam menghadapi persoalan hidup. Dengan perkataan lain, ia mempunyai integritas pribadi muslim. Proses pemantapan ini memakan waktu yang panjang. 6

\section{Hawa Nafsu}

Nafsu berasal dari bahasa Arab yaitu nafsun yang artinya niat.? Nafsu ialah keinginan hati yang kuat. Nafsu merupakan kumpulan dari kekuatan amarah dan sahwat yang ada pada manusia. Menurut Agus Sudjanto nafsu ialah hasrat yang besar dan kuat, ia dapat mempengaruhi seluruh fungsi jiwa. ${ }^{8}$ Hawa nafsu ini bergerak dan berkuasa di dalam kesadaran. Nafsu memiliki kecendrungan dan

${ }^{6}$ Hamka, Tasauf, Cet.18 (Jakarta: Pustaka Panjimas, 1993), hlm. 294.

7 Muhammad Yunus, Kamus Arab Indonesia, Jakarta: Yayasan Penyelenggara Penterjemaah, 1998), hlm. 124.

8 Agus Sudjanto, Psikologi Umum, (Jakarta: Bumi Aksara, 1995), hlm. 86. dalam kehidupan sehari-hari. Ia konsisten dalam mempedomani ketentuan-ketentuan syariat Islam sebagai pedoman tingkah laku

Asmal May, Potensi Energik Akblak

keinginan yang sangat kuat, ia mempengaruhi jiwa seseorang, inilah yang di sebut hawa nafsu.

Menurut Kartini Kartono nafsu ialah dorongan batin yang sangat kuat, memiliki kecenderungan yang sangat hebat sehingga dapat menganggu keseimbangan fisik. ${ }^{9}$ dilihat dari devinisi di atas berarti nafsu ialah suatu gejolak jiwa yang selalu mengarah kepada hal-hal yang mendesak, kemudian diikuti dengan keinginan pada diri seseorang untuk mencapai tujuan tertentu. Nafsu selalu mendorong kepada hal yang negatif yang perlu diperbaikidan dibina. Cara membina nafsu ini ialah dengn Tazkiyatu Al- nafsu, maksudnya pembersihan jiwa dan juga meliputi pembinaan dan pengembangan jiwa. ${ }^{10} \mathrm{Nafsu}$ dapat menyingkirkan semua pertimbangan akal, mempengaruhi peringatan hati nurani dan menyingkirkan hasrat baik yang lainya. Contoh nafsu bermain judi, minuman keras, nafsu membunuh, ingin memiliki dan nafsu yang lainnya, mengarah kepada keburukan, sehingga nafsu dapat berkuasa dan bergerak bebas kemana ia mau.

Dikalangan ahli tasawuf berpendapat bahwa nafsu ialah semua sifat tercela yang ada pada manusia dan mesti dikendalikan. Nabi bersabda: "Musuh yang paling berat disisimu ialah nafsumu dan berada diantara kedua punggung mu”Abu Ahmadi berpendapat bahwa nafsu ialah dorongan yang terdapat pada tiap-tiap manusia dan memberikan kekuatan bertindak untuk memenuhi kebutuhan-kebutuhan hidup tertentu. Nafsu ada pertaliannya dengan insting, tetapi pada insting, dampak keluarnya tidak sama. Nafsu dampak keluarnya jelas dalam berbagai bentuk dan cara.

Menurut ilmu akhlak, nasfu terbagi dua macam-macam yaitu:

1. Nafsu Individual (perseorangan) misalnya nafsu makan, minum, kebutuhan jasmani dan kesehatan.
${ }^{9}$ Lihat: Kartini Kartono, Psikologi Umum. (Jakarta: Mandar Maju, 1996), hlm.

${ }^{10}$ AF. Juelani, Penyucian Jiwa Mental, (Bandung: Hamzah, 1997), hlm. 44 
Al-Fikra: Jurnal Ilmiah Keislaman, Vol. 8, No. 1, Januari-Juni 2009

2. Nafsu sosial (kemasyarakatan) misalnya nafsu meniru, nafsu berkumpul dengan orang lain, mengeluarkan aspirasi, bermasyarakat dan bantuan-bantuan dari orang lain.

Perasaan yang hebat dapat menimbulkan gerak nafsu dan sebaliknya nafsu dapat menimbulkan akhlak baik dan akhlak buruk yang hebat, ada kalanya kemampuan berfikir dikesampingkan.

Nafsu terdapat pada tiap-tiap orang walaupun berbeda macam dan tingkatannya. Kebiasaan-kebiasaan yang baik dan pengaruhpengaruh positif pendidikan yang sudah tertanam dalam jiwa seseorang dapat mempengaruhi nafsu dan pertanyaan-pertanyaan nafsu, dengan jalan demikian nafsu dapat diperhalus. ${ }^{11}$

Nafsu merupakan salah satu potensi yang diciptakan Tuhan dalam diri manusia hingga ia dapat hidup, bersemangat dan lebih kreatif. Nafsu sangat penting bagi kehidupan manusia. Hanya saja mengingat tabiat nafsu itu berkecenderungan untuk mencari kesenangan, lupa diri, bermalas-malasan yang membawa kesesatan dan tidak pernah merasa puas, maka manusia harus dapat mengendalikannya agar tidak membawa kepada kejahatan.

Nafsu-nafsu yang ada pada manusia ada tiga yaitu:

a. Nafsu Amarah yaitu nafsu yang melahirkan bermacammacam keinginan untuk dapat dipenuhi. Nafsu ini belum memperoleh pendidikan dan bimbingan sehingga belum bisa membedakan mana yang baik dan mana yang buruk.

b. Nafsu Lawwamah yaitu nafsu yang menyebabkan manusia terlanjur untuk melakukan kesalahan dan menyesali perbuatan yang telah dilakukannya itu. Hanya sayangnya setelah itu ia buat lagi.

c. Nafsu Mutmainnah yaitu nafsu yang telah mendapatkan tuntutan, bimbingan, pemeliharaan yang baik dan pendidikan. Nafsu ini dapat mendatangkan ketenangan batin, melahirkan sikap dan akhlak yang baik, membentengi diri dari perbuatan keji dan munkar, bahkan menghalau aneka ragam kejelekan,

${ }^{11}$ Abu Ahmadi, Psikologi Umum, (Jakarta: PT. Rineka Cipta, 1998), hlm. 123.
Asmal May, Potensi Energik Akblak

selalu mendorong untuk melakukan kebajikan dan menjauhi maksiat. ${ }^{12}$

Harus diakui bahwa pada manusia ada daya yang menarik kepada yang tidak baik. Walaupun nafsu itu pada prinsipnya tidak jelek, tetapi menimbulkan kesulitan. Ada kalanya manusia hanya menghiraukan kesenangannya dan lupa batasannya, sehingga tidak jarang mengakibatkan kerugian terhadap kemanusiaannya sendiri dan di situ terjadi perbuatan buruk.

Manusia yang tidak berkepribadian selalu mengikuti nafsunya tanpa pertimbangan kemanusiaannya, yang dijadikan pedoman ialah kepuasannya. Nafsu yang sudah menjadi-jadi sehingga bukan lagi manusia yang menguasainya melainkan nafsulah yang menguasai manusia itu. ${ }^{13}$

\section{Adat Kebiasaan}

Adat menurut bahasa (etimologi) ialah aturan yang lazim diikuti sejak dahulu. ${ }^{14}$ Bisa ialah kata dasar yang mendapat imbuhan ke-an, artinya boleh, dapat atau sering. ${ }^{15}$ Menurut Nasraen adat itu ialah suatu pandangan hidup yang mempunyai ketentuan-ketentuan yang objektif, kokoh dan benar serta mengandung nilai mendidik yang besar terhadap seseorang dalam masyarakat. ${ }^{16}$

Kebiasaan terjadi sejak lahir. Lingkungan yang baik mendukung kebiasaan yang baik pula. Lingkungan dapat merubah kepribadian seseorang. Lingkungan yang tidak baik dapat menolak adanya disiplin dan pendidikan. Kebiasaan buruk mendorong kepada hal-hal yang lebih rendah, yaitu kembali kepada adat kebiasan primitif. Seseorang yang hidupnya dikatakan modern, tetapi lingkungan bersifat primitif

${ }^{12}$ Nur Uhbiyati, Ilmu Pendidikan Islam, Cet. ke 2 (Bandung: CV Pustaka Setia, 1998), hlm. 122. hlm. 57.

${ }^{13}$ Poedjawi Yatna, Etika Filsafat Tingkah Laku, (Jakarta: Rineka Cipta, 2000),

14 Muhamad Ali, Kamus Lengkap Indonesia Modern, (Jakarta: Pustaka Amani,1997), hlm. 2

${ }^{15}$ Ibid., hlm.42.

16 Lihat: Muh. Said, Etik Masyarakat Indonesia. (Jakarta: Pradnya Paramita, 1980), hlm. 100 
A1-Fikra: Jurnal Ilmiah Keislaman, Vol. 8, No. 1, Januari-Juni 2009

bisa berubah kepada hal yang primitif. Kebiasaan itu bisa timbul karena ada dalam diri pribadi seseorang itu yang dibawa sejak lahir.

Kebiasaan yang sudah melekat pada diri seseorang sukar untuk dihilangkan, tetapi jika ada dorongan yang kuat dalam dirinya untuk menghilangkan, ia dapat merobahnya. Misalnya kebiasaan seseorang bangun pukul 07.00 pagi ia sukar untuk bangun pukul 04.30 subuh. Menurut teori humanistik Plato dan Ariestoteles kebiasaan disebabkan adanya daya-daya yang mereka miliki semakin kuat, individunya mudah untuk cenderung sebagai masalah yang melekat pada dirinya. ${ }^{17}$ Seorang yang bangun pagi-pagi dengan adanya dorongan yang kuat, kemudian dilatih secara terus menerus, maka kebiasaan bangun pagipagi itu menjadi terbiasa dan tidak merasa berat karena adanya latihan secara terus menerus.

Kebiasaan ialah perbuatan yang berjalan dengan lancar seolaholah berjalan dengan sendirinya. Perbuatan kebiasaan pada mulanya dipengaruhi oleh kerja fikiran, didahului oleh pertimbangan akal dan perencanaan yang matang. Lancarnya perbuatan dikarenakan perbuatan itu seringkali di ulang-ulang.

Dalam percakapan sehari-hari kebiasaan tidak merupakan fungsi yang sama bagi manusia. Biasanya kebiasaan dalam perkataan dikerjakan dengan memperoleh dan menyimpan kata-kata, simbolsimbol pengalaman sadar. Kebiasaan dikaitkan dengan kegiatankegiatan nonverbal. Kata-kata muncul ketika seseorang berbicara, berbuat, humor, ocehan baik-buruk dalam bermacam-macam bentuk. Karakter pertama yang diucapkan ialah kelanjutan dari kata-kata terdahulu dan diulangi. Ini dapat dilihat bahwa diantara kata-kata terdapat beberapa kata yang diucapkan berulang kali, bahasa apapun di dunia ini. ${ }^{18}$ Hal ini timbul karena seorang telah dipengaruhi oleh lingkungannya, orang tua dan teman-temannya. Artinya apapun bahasa yang digunakan oleh lingkungan, orang tua dan temantemannya itulah yang di dapat.

${ }^{17}$ Made Pirdanta, Teori Belajar, (Jakarta: Rinika Cipta,1997), hlm. 199.

${ }^{18}$ Helen Lubis \& Taufik Hadi, Psikologi Kepribadian, (Surabaya: Bumi Aksara, 1984), hlm. 23.

90
Asmal May, Potensi Energik Akblak

Agar kebiasaan buruk seseorang dapat berubah menjadi baik, diperlukan berbagai bimbingan dari orang lain. Begitu juga dengan seorang anak sebelum ia memiliki kebiasaan yang buruk, maka dalam usia perkembangannya diberikan bimbingan yang benar. Kebutuhan bimbingan bagi seseorang disebabkan oleh perkembangan kebudayaan yang sangat pesat dan dapat mempengaruhi perkembangan masyarakat secara keseluruhan. ${ }^{19}$

Kebiasaan adalah rangkaian perbuatan yang dilakukan dengan sendirinya, tetapi masih dipengaruhi oleh akal pikiran. Pada permulaan sangat dipengaruhi oleh pikiran. Tapi makin lama pengaruh pikiran itu makin berkurang karena sering kali dilakukan. Kebiasaan merupakan kualitas kejiwaan, keadaan yang tetap, sehingga memudahkan pelaksanaan perbuatan. Menurut Soejono Soekanto kebiasaan sebagai perbuatan yang diulang-ulang dalam bentuk yang sama. Contoh, kebiasaan memberi hormat kepada orang lain yang lebih tua. Kebiasaan menghormati orang-orang yang lebih, merupakan suatu kebiasaan. ${ }^{20}$

Ada beberapa cara untuk mengetahui kebiasaan baik-buruk yang dapat ditangkap gejala-gejalanya sebagai berikut:

a. Metode mengatasi kebiasaan. Para Filosuf di dunia timur menjelaskan kebiasaaan ialah kesinambungan dari suatu pikiran atau tindakan untuk waktu yang lama, menyebabkan lekukan alur atau kanal yang terbentuk pada otak tindakannya menjadi tanpa sadar dan otomatis, kemauannya selalu timbul untuk mengulangi tindakan yang telah menjadi kebiasaan. Misalnya ketika seseorang mulai merokok ia masih memikirkan tentang menyalakan korek api kemudian ia menyalakan lagi tanpa berpikir lagi dan ini menjadi suatu kebiasaan. Untuk menghentikan kebiasan yang pertama harus

19 Oemar Hamalik, Psikologi Belajar dan Mengajar, (Bandung: Sinarbaru Algensindo, 1990), hlm. 392.

20 Soerjono Soekanto, Sosiologi Suatu Pengantar, Jakarta: Raja Grafindo Persada, 1990), hlm 32 
Al-Fikra: Jurnal Ilmiah Keislaman, Vol. 8, No. 1, Januari-Juni 2009

menghancurkan bentuk kebiasaan buruk itu, apapun resikonya. $^{21}$

b. Kekuatan kebiasaan. Kebanyakan orang mengibaratkan kekuatan kebiasaan dengan perkataan kebiasan itu natur yang kedua. Mereka bermaksud bahwa adat kebiasaan itu mempunyai kekuatan yang mendekati kepada natur yang pertama. Natur yang pertama ialah apa yang dibawa oleh manusia sejak ia dilahirkan. Kebiasaan dapat memberi bagi pekerjaan sifat, jalan yang tertentu dalam pikiran keyakinan, keinginan dan percakapan. Kekuatan kebiasan ialah yang menjadikan orang-orang tua menolak pendapat-pendapat baru dan penemuan-penemuan baru.

c. Merobah kebiasaan dapat dilakukan dengan cara memperhatikan pola terbaik, disesuaikan dengan unsur-unsur agama. Untuk merobah kebiasaan dapat dilakukan dengan cara; [1] Berniat sungguh dengan tiada diiringi keragu-raguan; [2] Janganlah mengizinkan bagi diri sendiri melakukan kebiasaan buruk, apa lagi menambah kebiasaan buruk yang lain; [3] Carilah waktu yang baik untuk mentabfidzkan niat dan ikutilah segala gerak jiwa yang menolong tabfidz tersebut. Kesukaran bukan dalam niat, tetapi dalam mentahfidzkannya; [4] Jagalah pada diri kekuatan penolak dan pemelihara agar selalu hidup dalam jiwa dengan mendermakan perbuatan yang kecil-kecil tiap-tiap hari untuk mengekang hawa nafsu yang tidak baik. ${ }^{22}$

Semua perbuatan baik dan buruk itu menjadi adat kebiasaan karena adanya kecenderungan hati terhadapnya dan menerima kecenderungan tersebut dengan disertai perbuatan berulang-ulang secukupnya. ${ }^{23}$ Kebiasaan itu ditentukan oleh lingkungan sosial,

${ }_{21}$ Doug Hooper, Berpikir dan Bertindak, Cet.2 (Semarang: Bahara Prizo, 2000), hlm. 70.

22 Lihat: Ahmadi Amin, Etika Ilmu Akblak, Cet. ke 5 Jakarta: Bulan Bintang, 1998), hlm. 24-28.

${ }^{23}$ Sahilun A.Nasir, Tujuan Akblak, (Surabaya: Al-Ikhlas), hlm. 48.
Asmal May, Potensi Energik. Akblak

kebudayaan dan dikembangkan manusia sejak ia lahir. Kebiasaankebiasaan mendapatkan bentuk-bentuknya yang tetap berkat ulanganulangan dan sukses. Jika sukses, akan di ulang kembali dan jika tidak sukses akan ditinggalkan.

Kebiasan ialah tingkah laku yang sudah distabilkan. Umumnya pembentukan kebiasaan itu di bantu oleh refleks-reflek, maka refleks itu menjadi khas dasar bagi pembentukan kebiasaan. Pada akhirnya kebiasaan itu berlangsung otomatis dan mekanis, terlepas dari pemikiran dan kesadaran, namun sewaktu-waktu pikiran dan kesadaran bisa difungsikan lagi untuk memberikan pengarahan baru bagi pembentukan kebiasaaan baru. ${ }^{24}$

Dalam segala tempat dan waktu manusia terpengaruh oleh adat istiadat golongan dan bangsanya, karena mereka hidup dalam lingkungan. Tiap-tiap bangsa mempunyai adat istiadat yang tertentu dan menganggap baik bila mengikutinya. Contoh adat-istiadat ialah dalam mendidik anak, seperti dalam kejurusan adat istiadat dan menanam perasaan cinta kepada adat istiadat, jika seseorang menyalahi adat-istiadat maka orang tersebut sangat di cela dan dianggap keluar dari golongannya.

Adat menurut bahasa (etimologi) ialah aturan yang lazim diikuti sejak dahulu. ${ }^{25}$ Kebisaan ialah kata dasar yang mendapat imbuhan kean, artinya boleh, dapat atau sering. Menurut Nasraen adat itu ialah suatu pandangan hidup yang mempunyai ketentuan-ketentuan yang objektif, kokoh dan benar serta mengandung nilai mendidik yang besar terhadap seseorang dalam masyarakat. ${ }^{26}$

Adat merupakan hukum-hukum yang ditetapkan untuk mengatur hubungan perorangan, hubungan masyarakat dan untuk mewujudkan kemashalatan dunia. Hukum-hukum ini dapat dipahami maknanya, selalu diperhatikan uruf-uruf dan kemasalahatan, dapat berubah menurut perubahan masa, tempat dan situasi. Oleh karena itu hukum yang mengenal adat, kebanyakan hukumnya bersifat

${ }^{24}$ Kartini Kartono, Psikologi..., hlm. 101-102.

25 Muhamad Ali, Kamus Lengkap...., hlm. 2.

${ }^{26}$ Muh. Said, Etika...., hlm. 100 
A1-Fikra: Jurnal Ilmiah Keislaman, Vol. 8, No. 1, Januari-Juni 2009

keseluruhan, berupa kaidah-kaidah yang umum dan disertai illatillatnya.

Masalah-masalah adat yang dijelaskan sunnahnya ialah keluarga, perkawinan, pusaka dan kemasyarakatan. Bagian adat atau muamalah pada umumnya diterangkan secara mujmal, sehingga para mujtahidin dapat menyusun hukum yang sesuai dengan kehendak massa. Ada adat pribadi dan adat masyarakat. Adat adalah kebiasaan yang sudah melembah, sehingga ia bersifat peraturan, suatu kebiasaan ketika dipandang sebagai kaidah (norma) meningkatkan ia menjadi adat Nilai-nilai adat berfungsi sebagai pedoman hidup manusia dalam masyarakat, tetapi sebagai konsep suatu nilai adat itu bersifat sangat umum mempunyai ruang lingkup yang sangat luas, biasa sulit diterangkan secara rasional dan nyata. Namun, justru karena sifatnya yang umum, luas dan tak kongkrit, maka nilai-nilai adat dalam suatu kebudayaan berada dalam daerah emosional di alam jiwa para individu yang menjadi warga dari kebudayaan yang bersangkutan.

Sebuah adat-istiadat yang dilakukan dalam kehidupan sehari-hari tak jarang melahirkan dua dampak yaitu dampak positif dalam kehidupan dan dampak negatifnya. Dalam sebuah adat yang bermain dalam masyarakat dapat memberikan sebuah wacana baru untuk membentuk sebuah generasi selanjutnya. ${ }^{27}$

Diantara adat istiadat sesuatu bangsa, berasal dari perbuatanperbuatan yang dilakukan oleh nenek moyangnya, karena terdorong oleh instingnya, ada yang berasal dari kebetulan, meskipun tidak berdasarkan kepada akal seperti harapan baik bagi beberapa golongan manusia atas perbuatan yang mereka lakukan pada waktu tertentu.

Sebagian adat istiadat itu lantaran nenek moyang mereka dahulu menganggap baik kepada sesuatu perbuatan yang bersifat berani meskipun tidak berguna. Adat istiadat itu berasal dari perbuatan orang-orang dahulu, mencoba melakukan perbuatan-perbuatan yang akhirnya mengetahui yang berguna dan bermanfaat, lalu mengetahui yang merugikan, maka mereka menyingkirkannya dan

27 TM.Hasbi Ash Shiddieqy, Pengantar Ilmu Fiqh, Cet 2 (Semarang: Pustaka Riski Putra, 1999), hlm. 20
Asmal May, Potensi Energik. Akblak

memperingatkan orang-orang agar menjauhi. Perintah-perintah adat istiadat dilakukan dan larang-larangan disingkirkan karena beberapa jalan yang ditempuh yaitu:

1. Pendapat umum tentang adat biasanya selalu memuji pengikut-pengikut adat-istiadat dan mengeluarkan orangorang yang menyalahinya dari dalam kelompoknya. Demikianlah sebab-sebabnya segolongan bangsa mentertawakan adat istiadat bangsa lain yang menyalahi adat istiadat mereka.

2. Apa yang diriwayatkan turun-turun dari hikayat-hikayat dan kufarat-kufarat yang menganggap bahwa syetan dan jin membalas dendam kepada orang-orang yang menyalahi perintah-perintah adat istiadat. Malaikat mendoakan, pahala dari Tuhan bagi yang mengikuti adat istiadatnya.

3. Upacara keramaian, pertemuan yang menggerakkan perasaan dan yang mendorong bagi para hadirin untuk mengikuti maksud dan tujuan upacara itu. Seperti mengikuti upacara adat-istiadat, upacara kematian, upacara pengantin, upacara ziarah kubur, dan upacara lainnya.

\section{Lingkungan}

Lingkungan ialah ruang lingkup luar yang berinteraksi dengan insan yang dapat berwujud benda-benda seperti air, udara, bumi, langit, matahari. Berbentuk selain benda seperti insan, pribadi, kelompok, institusi, sistem, undang-undang dan adat kebiasaan. Lingkungan dapat memainkan peranan dan pendorong terhadap perkembangan kecerdasan, sehingga manusia dapat mencapai taraf yang setinggi-tingginya dan sebaliknya juga dapat merupakan penghambat yang menyekat perkembangan, sehingga seorang tidak dapat mengambil manfaat dari kecerdasan yang diwarisi. ${ }^{28}$

Lingkungan dapat juga suatu yang melingkupi tubuh manusia yang hidup yaitu meliputi tanah dan udara. Lingkungan manusia yaitu

28 Zakiah Daradjat, Ilmu Pendidikan Islam, (Jakarta: Bumi Aksara, 1994), hlm. 
Al-Fikra: Jurnal Ilmiah Keislaman, Vol. 8, No. 1, Januari-Juni 2009

apa yang mengelilinginya seperti Gunung, lautan, udara, sungai, negeri, perkampungan dan masyarakat disekitarnya.

Lingkungan ada dua jenis yaitu:

1. Lingkungan Alam. Alam ialah seluruh ciptaan Tuhan baik di langit dan di bumi selain Allah. Lingkungan alam telah lama menjadi perhatian ahli sejarah sejak zaman Plato hingga sekarang. Alam dapat menjadi aspek yang mempengaruhi dan menentukan tingkah laku manusia. Lingkungan alam dapat menghalangi bakat seseorang, namun alam juga dapat mendukung untuk meraih segudang prestasi. Sebagai contoh; Masyarakat yang tinggal di gunung-gunung, di hutan-hutan, mereka akan hidup sebagai seorang pemburu dan petani yang berpindah-pindah. Masyarakat yang hidup di pantai, kehidupan mereka akan menjadi nelayan dan tingkah-laku mereka cenderung beralifiasi ke laut. Masyarakat tinggal di daerah kutub yang dingin, mereka berpakaian tebal dan memiliki cara yang khas. Itulah lingkungan alam. Alam dapat membentuk kepribadian manusia sesauai lingkungan alamnya.

2. Lingkungan Pergaulan. Lingkungan ini mengandung susunan pergaulan yang meliputi manusia seperti di rumah, di sekolah, di tempat kerja dan kantor pemerintahan. Lingkungan pergaulan dapat merobah keyakinan, akal-fikiran, adat istiadat, pengetahuan dan akhlak. Pendeknya dapat dikatakan bahwa lingkungan pergaulan dapat membuahkan kemajuan dan kemunduran manusia. Dalam masa kemundurunnya, manusia leih banyak terpengaruh dengan lingkungan alam. Lingkungan pergaulanlah yang banyak membentuk kemajuan pikiran, dan kemajuan teknologi namun juga dapat menjadikan prilaku baik dan buruk. Lingkungan pergaulan terbagi menjadi tujuh kelompok yaitu; [a] Lingkungan dalam rumah tangga; [b] Lingkungan sekolah; [c] Lingkungan pekerjaan; [d] Lingkungan organisasi; [e] Lingkungan jama'ah; [f] Lingkungan ekonomi/perdagangan; [g] Lingkungan pergaulan bebas/umum.
Asmal May, Potensi Energik. Akblak

Manusia itu walaupun dipengaruhi oleh lingkungan alam atau lingkungan pergaulan, tapi ia diberi akal. Dengan akal ia dapat memikirkan sampai batas yang tertentu, menentukan lingkungan yang cocok dan beradaptasi secara baik.

Lingkungan pergaulan mempunyai pengaruh yang berlawanan, terkadang menguatkan hidup manusia dan meninggalkannya dan kadang melemahkannya atau mematikannya. Seperti tumbuhan yang hidup dalam lingkungannya yang buruk lalu lemah dan mati, dan dalam lingkungan yang baik lalu tumbuh dan bertunas dengan segar. Demikian juga dengan manusia, bila ia tumbuh dalam lingkungan yang baik terdiri dari rumah yang teratur, sekolah yang maju dan kawan yang sopan, mempunyai undang-undang yang adil dan beragama dengan agama yang benar, tentu akan menjadi orang yang baik. Sebaliknya dari itu tentu akan menjadi orang yang jahat. Oleh karena itu dalam bergaul harus melihat siapa teman bergaulnya. Orang-orang yang berdosa seperti pencuri, pembunuh dan pemalas harus dijauhi karena tidak terdidik.

Lingkungan merupakan salah satu faktor pendidikan Islam yang berpengaruh terhadap anak didik. Lingkungan yang dapat memberi pengaruh terhadap anak didik dapat dibedakan menjadi tiga kelompok; [1] Lingkungan yang acuh tak acuh terhadap agama; [2] Lingkungan yang berpegang teguh kepada tradisi agama; [3] Lingkungan yang mempunyai tradisi agama dengan sadar dan hidup dalam lingkungan agama. ${ }^{29}$

\section{Kehendak dan Takdir}

Kehendak menurut bahasa (etimologi) ialah kemauan, keinginan dan harapan yang keras. Kehendak yaitu fungsi jiwa untuk dapat mencapai sesuatu, merupakan kekuatan dari dalam hati, bertautan dengan fikiran dan perasaan. Kehendak merupakan salah satu fungsi kejiwaan dari kekuatan aktifitas jiwa dalam kelompok trikhotonomi yang dinamakan konasi. Suatu kekuatan yang dapat melakukan gerakkan, kekuatan yang timbul dari dalam diri manusia. Untuk melakukan suatu 175

29 Zulhairini, Filsafat Pendidikan Islam, (Jakarta: Bumi Aksara, 1991), hlm. 
Al-Fikra: Jurnal Ilmiah Keislaman, Vol. 8, No. 1, Januari-Juni 2009

perbuatan yang diingini maupun yang dihindari itu dinamakan kehendak. Kehendak ialah suatu kekuatan yang mendorong melakukan perbuatan untuk mencapai suatu tujuan. Tujuan itu dapat dibedakan menjadi dua macam; [a] Tujuan positif yaitu yang mendekati atau mencapai sesuatu yang dikehendaki; [b] Tujuan negatif yaitu tujuan yang menjauhi atau menghindari sesuatu yang tidak diinginkan setiap perbuatan kehendak bersifat teleologis atau finalistis, artinya kehendak yang mengarah kesuatu tujuan tidak baik atau kejahatan. Sehingga setiap perbuatan kehendak jiwa benar-benar aktif untuk mencapai suatu tujuan.

Kehendak merupakan suatu kekuatan dari beberapa keuatan, seperti listrik dan magnit. Penggerak itu timbul, menghasilkan kehendak dan segala sifat manusia, kekuatannya seolah-olah tidur nyenyak sehingga dibangunkan oleh kehendak. Penggerak merupakan kemahiran penggunaan, kekuatan akal, ahli pikiran kepada pekerjaan, tahu akan wajib, mengetahui apa yang seharusnya dan tidak seharusnya. Kehendak mempunyai dua macam perbuatan; [a] Perbuatan yang menjadi pendorong, yakni kadang-kadang mendorong kekuatan manusia supaya berbuat seperti, membaca, mengarang atau pidato; [b] Perbuatan menjadi penolak, terkadang mencegah perbuatan tersebut seperti melarang berkata atau berbuat.

Kehendak menurut Kant adalah satu-satu permata yang menyinari mata hati dengan sinar yang tertentu. Kehendak itu bisa terkena penyakit seperti tubuh, penyakit-penyakit itu adalah sebagai berikut; [a] kehendak yang lemah dan [b] kehendak yang kuat.

Kekuatan kehendak adalah rahasia kemenangan dalam hidup dan tanda bukti bagi orang-orang yang besar. Kehendak yang sakit dapat diobati dengan beberapa macam obat; [a] bila kehendak itu lemah dapat diperkuat dengan latihan; [b] kehendak dihidupkan dengan agama, dengan mmenjalankan syariat sehingga dapat terbimbing kepada yang baik; [c] memperkenalkan jiwa pada jalan yang baik dan menghindari jalan yang buruk menurut ajaran agama.

Allah SWT adalah zat yang maha kuasa di seluruh alam semesta ini. Dia mengatur segala sesuatu yang ada di dalam kerajaan-Nya dengan kebijaksanaan dan kehendak-Nya. Maka dari itu apa saja yang 98
Asmal May, Potensi Energik. Akblak.

terjadi di alam semesta ini, semuanya berjalan sesuai dengan kehendak yang telah direncanakan. Sejak semula Allah membuat peraturanperaturan yang telah ditetapkan dalam alam yang maujud ini dan berjalan sesuai kehendaknya.

Allah yang menciptakan dan Allah bebas mamilih siapapun dari makhluknya sesuai dengan apa yang telah dikehendaki, sebab Dia adalah pengatur secara mutlak. Tidak seorang pun yang mampu memiliki hak untuk memilih yang sesuai dengan kehendakNya. Allah berfirman:

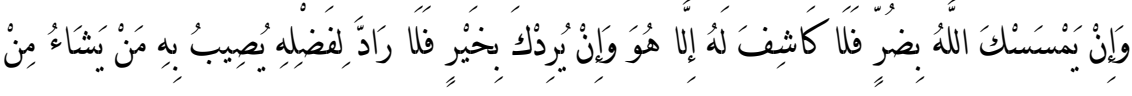

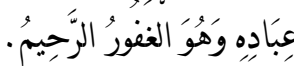

Jika Allah melimpahkan bahaya kepadamu, maka tidak ada yang dapat menghilangkennya kecuali Dia. Jika Allah menghendaki kebaikan bagi kamu, maka tak ada yang dapat menolak kurnia-Nya. Dia memberikan kebaikan itu kepada siapa yang dikehendaki-Nya di antara hambahamba-Nya dan Dia-lah Yang Maha Pengampun lagi Maha Penyayang. (Q.S. Yunus: 107).

Dari ayat ini Allah berkehendak mengatur dalam lingkungan kerajaan-Nya, menurut kehendakNya sendiri, mengikuti dasar kebijaksanaan dan rahmatNya. Ini adalah hak mutlak yang tidak dapat diganggu-gugat. Apabila seseorang itu ditimpa bencana, pasti tidak ada yang dapat menyelamatkannya selain Allah. Tetapi sebaliknya apabila Allah menghendaki seeorang itu memperoleh kebaikan, juga tidak seorangpun yang dapat menghalang-halangiNya.

Kehendak bukanlah suatu kekuatan, tetapi merupakan tempat penerapan seluruh kekuatan. Tuhan menciptakan dengan kehendak. Karena itu, apa yang disebut dengan kehendak dalam diri, pada hakikatnya adalah suatu kekuatan Tuhan, jika ada rahasia yang dapat dipelajari di balik misteri dunia. Rahasia itu adalah kehendakNya.

Dalam sejarahnya, manusia telah mampu melakukan hal-hal yang besar dengan kehendak, keberhasilan dan kegagalan adalah fenomena dari kehendak. Hanya fenomena kehendak yang mengantarkan seseorang kepada kesuksesan. Bila kehendak gagal, 
A1-Fikra: Jurnal Ilmiah Keislaman, Vol. 8, No. 1, Januari-Juni 2009

betapapun layak dan pintarnya seseorang dia akan gagal juga, karena itu kehendak bukan merupakan suatu kekuatan manusia tetapi kekuatan Ilahi dalam diri manusia. Mekanisme kerjanya bersama pikiran masih lebih besar dibandingkan tubuh, karena tak ada manusia dapat menahan pikirannya dalam sesaat, bila tak dapat berkonsentrasi, tak dapat menjaga pikirannya untuk diam sesaat, berarti kehendak telah menggagalkannya. ${ }^{30}$

Tabiat alami kehidupan yang dijalani manusia adalah kehendak. Kehendak tidak hanya membutuhkan perjuangan untuk menjalani kehidupan, tetapi diri sendiri, pikiran, hasrat dan keinginan dapat melemah kehendak. Bagi manusia bahwa motif meningkatnya kegiatan merupakan kehendak. Tetapi pada akhirnya dapat menemukan motif, merampas kehendak dari dalam diri manusia.

Motif ialah suatu bayangan pada inteligensia, walaupun semakin tinggi motif, semakin tinggi jiwa, semakin besar motif, semakin besar kehendak manusia. Kehendak berada dalam pengendalian berlawanan dengan imajinasi, yang bekerja tanpa kendali. Karena jika seseorang ingin mengendalikannya dia malah memanjakannya. Kehendak secara sistematis dikembangkan sesuai pendisiplinan tubuh terlebih dahulu. Setelah itu kedisiplinan pikiran harus melalui konsentrasi.

Tatkala pikiran memikirkan sesuatu yang lain, yang bersangkutan mengaharapkan memikiran sesuatu, maka pemikiran itu timbul dalam waktu tertentu. Maka pikiran itu menjadi sangat tidak tenang, ia tidak mau untuk tenang sejenak karena terbiasa tanpa disiplin. Kehendak dapat diperkuat melalui latihan, dengan mendorongnya untuk menanggulangi rintangan, baik rintangan dalam diri atau di luar diri, melalui tindakan berlawanan dengan kecondongan diri sendiri.

Adapun takdir yaitu ketetapan Tuhan, apa yang sudah ditetapkan Tuhan sebelumnya atau nasib manusia. Secara bahasa (etimologi) takdir ialah ketentuan jiwa, yaitu suatu peraturan tertentu yang telah dibuat Allah SWT baik aspek struktural maupun aspek

30 Inayat Khan, Demensi Spiritual Psikologi, (Bandung: Pusaka Hidayah, 2000), hlm. 45-46.
Asmal May, Potensi Energik. Akblak

fungsionalnya untuk segala yang ada dalam alam semesta yang maujud ini. ${ }^{31}$

Bermacam-macam peristiwa yang terjadi di alam ini, ada yang disukai dan ada pula yang dihindari, seperti kaya, senang, sehat, sukacita semuanya adalah kehendak dari jiwa manusia yang merupakan takdir Tuhan. Demikian pula dengan miskin, susah, sakit, dukacita semuanya ini tidak diinginkan tetapi ia datang juga. Beragam cara untuk menolaknya, tetapi lain yang diinginkan lain yang tiba, lain yang diharapkan lain pula yang terjadi. Beginilah teka-teki hidup, semuanya itu menjadi pertanda bahwa ada yang lebih berkuasa dari diri manusia. Dia telah membuat ketetapan atas segala sesuatu kemudian. Dia tetapkan ketentuan itu dalam bentuk takdir. Segala kejadian akan terjadi menurut garis yang telah ditentukanNya.

Garis takdir itu gaib bagi manusia, tak seorangpun yang mengetahui takdir yang telah ditentukan Tuhan bagi dirinya, tidak ada yang tahu apa yang akan terjadi atas dirinya besok. Tetapi sekalipun takdir itu telah ditetapkan, namun Tuhan memberi kuasa juga kepada manusia untuk berusaha dan berikhtiar dalam lingkungan takdir. Ada enam tingkatan Tuhan menciptakan kadar dan takdir-Nya, keenam tersebut adalah; [a] qadar yang diciptakan Allah pada Azal; [b] pentakdiran sebelum terjadinya langit dan bumi, sedangkan arasy sudah diciptakan; [c] pentakdiran yang dilakukan Tuhan tentang celaka dan bahagia yang ditentukan Tuhan sebelum manusia dijadikan; [d] qadar yang ditentukan Tuhan terhadap manusia tentang amal, kecelakaan dan kebahagian ketika di dalam rahim ibu; [e] pentakdiran yang dilakukan Tuhan di setiap malam kadar, pentakdiran ini dinamai pentakdiran Hauly (takdir tahunan); dan [f] takdir yang ditentukan Tuhan untuk setiap hari atau takdir yaumy.

Keenam takdir ini sudah diatur oleh Allah sedemikian elok dan adil, sehingga manusia dan makhluk seluruhnya tinggal menjalaninya

31 Muhammad Arezy, Diferensial dan Integral Takdir, Cet. ke 2 Jakarta: Kalam Mulia, 1996), hlm. 1 
Al-Fikra: Jurnal Ilmiah Keislaman, Vol. 8, No. 1, Januari-Juni 2009

sesuai dengan sunnah yang berlaku di semesta ini. ${ }^{32}$ Kehendak artinya bermaksud, takdir diambil dari kata qadara yang artinya member ukuran. Takdir diartikan sebagai ketentuan yang tidak dapat diganggu gugat.

Aliran-aliran dalam ilmu teologi berpendapat tentang takdir secara beragam, yaitu:

a. Aliran natipisme. Aliran ini mengatakan, bahwa segala sesuatu, khususnya manusia telah ditakdirkan Tuhan sejak lahir. Menurut teori ini manusia itu tidak bisa berkehendak secara luas karena takdirnya sudah ditentukan Tuhan sejak lahir. Sejalan dengan hal itu, dalam aliran teologi Islam yang di kenal dengan aliran jabariah ia mengatakan, manusia tidak bisa berbuat apa-apa, karena takdirNyalah manusia dapat beraktifitas dengan baik namun tidak bebas karena manusia terikat dengan kehendak mutlak Tuhan. ${ }^{33}$ Dari sekian banyak ayat Al-Qur'an, dipahami bahwa semua makluk hidup telah ditetapkan takdirnya oleh Allah. Manusia tidak dapat melampaui batas ketetapan Allah, Allah menetapkan dan menunjukkan mereka ke arah yang seharusnya mereka tuju. Menurut teori ini, manusia tidak bisa mengubah takdirnya karena semua itu kehendak mutlak Tuhan.

b. Aliran empirisme. Aliran ini kebalikan dari aliran natipisme. Pakarnya ialah John Lock. Ia mengatakan, "Takdir itu bisa dirobah oleh manusia itu sendiri." Kehendak yang ingin dicapai oleh manusia dapat diraih selagi bekerja sungguhsungguh, menggunakan ilmu, kerja keras dan ulet pasti tercapai.

c. Aliran konpergensi. Aliran ini merupakan aliran yang netral, aliran ini mengatakan, "Manusia itu dalam berkehendak sudah terikat sejak lahir, akan tetapi bisa dirobah oleh manusia itu sendiri." Seyogyanya takdir itu datang dari lahir tapi ada

32 Lihat: Yunasril Ali, Pelita Hidup Menuji Ridha Ilabi (Jakarta: Kalam Mulia, 1991), hlm. 118-122.

${ }^{33}$ Harun Nasution, Theologi Islam, (Jakarta: UI.Press,1986), hlm. 31.
Asmal May, Potensi Energik Akblak

kaitannya dengan usaha manusia itu sendiri. Dengan adanya tiga teori ini, manusia tidak bebas dalam berkehendak karena terikat dengan bawaan sejak lahir, akan tetapi kehendak yang belum tercapai, dapat diraih dengan usaha sendiri. Diantara pokok ajaran Islam yang sering menjadi sasaran kritikan orang non muslim dan dari Islam yang kurang mengerti agama, ialah tentang iman kepada takdir Allah. ${ }^{34}$ Alangkah salahnya orang berpandangan, hanya memandang satu segi saja dari takdir Allah, padahal Allah juga menyebutkan dalam Al-qur'an:

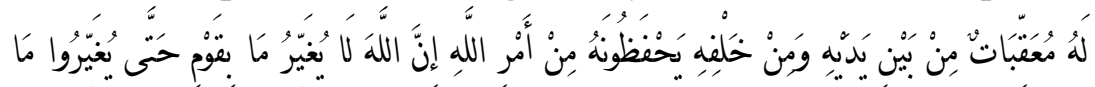

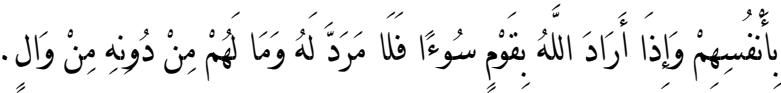

Bagi manusia ada malaikeat-malaikat yang selalu mengikutinya bergiliran, di muka dan di belakangnya, mereka menjaganya atas perintah Allah. Sesungguhnya Allah tidak mengubah keadaan sesuatu kaum sehingga mereka mengubah keadaan yang ada pada diri mereka sendiri. Dan apabila Allah menghendaki keburukan terhadap sesuatu kaum, maka tak ada yang dapat menolaknya; dan sekali-kali tak ada pelindung bagi mereka selain Dia. (Q.S. Ar-Ra'du: 11).

Dalam Alqur'an berkali-kali disebutkan masalah takdir itu seperti; [a] segala sesuatu terlaksana dengan takdir Allah; [b] segala sesuatu dalam perbendaharaan takdir Allah; [c] segala sesuatu diciptakan dengan kekuatan takdir Allah. ${ }^{35}$

Makna takdir ialah suatu peraturan tertentu yang telah dibuat oleh Allah untuk segala yang ada dalam alam semesta yang maujud. Peraturan-peraturan tersebut ialah yang merupakan undang-undnag umum atau kepastian-kepastian yang diikatkan di dalamnya antara sebab dengan masalahnya, juga antara sebab dan akibatnya.

${ }^{34}$ Zakiah Daradjad, Islam Dan Kesehatan Mental. Cet. ke 2. (Jakarta: Gunung Agung, 1982), hlm. 93.

${ }^{35}$ Lihat: Q.S. Ali-Imran: 166, Q.S.Yusuf: 67, 68, Q.S. Al-Ahzab: 17 dan Q.S. Ar-Ra'ad: 8 
A1-Fikra: Jurnal Ilmiah Keislaman, Vol. 8, No. 1, Januari-Juni 2009

Imam Nawawi, memberikan defenisi takdir sebagai sesuatu yang maujud ini adalah kehendak Allah, sudah digariskan sejak zaman Qidam dahulu. Allah Maha Mengetahui apa saja yang akan terjadi atas segala sesuatu dalam waktu yang telah ditentukan, sesuai dengan garis yang telah ditetapkanNya. Terjadinya itu nanti pasti akan cocok menurut sifat-sifat dan keadaannya khusus tepat seperti yang digariskan oleh Allah SWT.

Makna yang gamblang dari takdir itu, bahwa Allah membuat beberapa ketentuan, peraturan dan undang-undang yang diterapkan untuk segala yang maujud ini dan bahwa segala sesuatu yang maujud itu pasti akan berlaku, beredar dan berjalan tepat dan sesuai dengan apa yang telah dipastikan dalam ketentuan, peraturan dan undangundang. Beriman kepada takdir adalah sebagian dari kepercayaan yang ditanamkan benar-benar dalam hati setiap orang muslim.

Adapun hikmah keimanan kepada takdir, supaya kekuatan dan kecakapan manusia itu dapat mencapai kepada pengertian untuk menyadari adanya peraturan dan ketentuan-ketentuan Tuhan, kemudian dilaksanakan untuk membina dan membangun akhlak baik dengan bersendikan ajaranNya, juga untuk mengeluarkan harta benda yang terdapat dalam perbendaharaan bumi agar dapat diambil kemanfaatannya.

Beriman kepada takdir merupakan suatu kekuatan yang dapat membangkitkan kegiatan bekerja. Beriman kepada takdir itu dapat memberikan pelajaran kepada manusia bahwa segala sesuatu yang ada dalam alam semesta ini hanyalah berjalan sesuai dengan kebijaksanaan yang telah digariskan oleh zat yang Maha Tinggi. ${ }^{36}$

\section{Kesimpulan}

Untuk melakukan sesuatu manusia selalu dilatarbelakangi oleh berbagai potensi yang sangat energik. Kekuatan energik itu menyatu dalam keyakinan seseorang yang dalam Islam disebut keimanan. Keimanan dapat bertambah atau berkurang karena pengaruh yang hlm. 144

36 Sayid Sabiq, Aqidah Islam, Cet. ke 9 (Bandung, CV. Diponegoro, 1996),
Asmal May, Potensi Energik Akblak

datang dari dalam maupun luar dirinya. Faktor dari dalam diri manusia berupa dorongan hawa nafsu lebih dominan mempengaruhi perbuatan manusia. Martabat manusia ditentukan oleh perbuatannya dan perbuatannya itu ditentukan oleh kehendak hati, ikhtiar dan pilihan hidup yang dijatuhkan. Akal berfungsi menuntun manusia ke jalan yang benar dan wahyu berfungsi menyinari akal. Oleh karena itu akal tanpa agama dan wahyu dapat kehilangan arah dan gampang dikendalikan hawa nafsu.

\section{Bibliografi}

Ahmadi, Abu, Psikologi Umum, (Jakarta: PT. Rineka Cipta, 1998).

Ali, Muhamad, Kamus Lengkap Indonesia Modern, (Jakarta: Pustaka Amani, 1997).

Ali, Yunasril, Pelita Hidup Menuju Ridha Ilahi (Jakarta: Kalam Mulia, 1991).

Amin, Ahmad, Etika Ilmu Akblak. (Jakarta: Bulan Bintang, 1996).

Arezy, Muhammad, Diferensial dan Integral Takdir, Cet. ke 2 (Jakarta: Kalam Mulia, 1996)

Banna, Syekh Hasan al-, Aqidah Islam, Cet. ke 2 (Bandung: PT.AlMaa'rif, 1983).

Daradjat, Zakiah, Dasar-Dasar Agama Islam, Cet. ke 2 (Jakarta: Universitas Terbuka, 2002).

Ilmu Pendidikan Islam, (Jakarta: Bumi Aksara, 1994).

, Islam Dan Kesehatan Mental. Cet. ke 2 (Jakarta: Gunung Agung, 1982).

Gazalba, Sidi, Asas Kebudayaan Islam, Cet. ke 1 (Jakarta: Bulan Bintang, 1978).

Hamalik, Oemar, Psikologi Belajar dan Mengajar, (Bandung: Sinarbaru Algensindo, 1990).

Hamka, Tasauf, Cet.18 (Jakarta: Pustaka Panjimas, 1993). 
Al-Fikra: Jurnal Ilmiah Keislaman, Vol. 8, No. 1, Januari-Juni 2009

Hooper, Doug, Berpikir dan Bertindak, Cet. ke 2 (Semarang: Bahara Prizo, 2000).

Juelani, AF., Penyucian Jiwa Mental, (Jakarta: Aamzah, 1997).

Kartono, Kartini, Psikologi Umum. (Jakarta: Mandar Maju,1996).

Khan, Inayat, Demensi Spiritual Psikologi, (Bandung: Pusaka Hidayah, 2000).

Lubis, Helen \& Taufik Hadi, Psikologi Kepribadian, Jakarta: Bumi Aksara, 1994).

Nasir, Sahilun A., Tujuan Akhlak, (Surabaya: Al-Ikhlas, 1999).

Nasution, Harun, Teologi Islam, (Jakarta: UI.Press,1986).

Pirdanta, Made, Teori Belajar, (Jakarta: Rinika Cipta,1997).

Sabiq, Sayid, Aqidah Islam, Cet. Ke 9 (Bandung, CV.Diponegoro, 1996).

Said, Muh., Etik Masyarakat Indonesia. (Jakarta: Pradnya Paramita, 1980).

Shiddieqy, TM. Hasbi Ash, Pengantar Ilmu Fiqh, Cet. ke 2 (Semarang: Pustaka Riski Putra, 1999).

Soekanto, Soerjono, Sosiologi Suatu Pengantar, (Jakarta: Raja Grafindo Persada, 1990).

Sudjanto, Agus, Psikologi Umum, (Jakarta: Bumi Aksara,1995).

Sumantri, Jujun S. Surya, Filsafat, Cet. ke 16 (Jakarta: Total Grafika Indonesia, 2003).

Suryabrata, Sumadi, Psikologi Kepribadian (Jakarta: Raja Grafindo Persada, 1995).

Uhbiyati, Nur, Ilmu Pendidikan Islam, Cet. ke 2 (Bandung: CV Pustaka Setia, 1998).

Yatna, Poedjawi, Etika Filsafat Tingkah Laku, (Jakarta: Rineka Cipta, 2000).
Asmal May, Potensi Energike Akblak

Yunus, Muhammad, Kamus Arab Indonesia, Jakarta: Yayasan Penyelenggara Penterjemaah, 1998).

Zulhairini, Filsafat Pendidikan Islam, (Jakarta: Bumi Aksara, 1991). 